\author{
KS. DARIUSZ KURZYDŁO \\ UKSW WARSZAWA \\ ORCID 0000-0002-1777-8746
}

\title{
NOWI ADRESACI KATECHEZY
}

Katecheza jest dziełem Kościoła skierowanym do ludzi współczesnych. Paweł VI zaznacza: „Głoszenie Ewangelii ludziom naszych czasów, pełnym nadziei, ale również często nękanym lękiem i trwogą, należy uważać bez wątpienia za służbę świadczoną nie tylko społeczności chrześcijan, ale także całej ludzkości” (EN 1) i zachęca do troski, by Kościół „stał się bardziej zdatny do głoszenia Ewangelii ludziom tegoż stulecia" (EN 2). Paweł VI przypomina, że pierwsi chrześcijanie, dogłębnie zrozumiawszy naukę Jezusa Chrystusa, przekazali ją światu w sposób dla niego zrozumiały, i ten okres rozwoju Kościoła należy uznać za wzorcowy (EN 49-51). Papież wskazuje na zróżnicowanie procesu formacji, katechezie przydzielając zadanie pogłębiania wiary, jej umacniania, żywienia i czynienia coraz dojrzalszą; katecheza powinna być nasycona „sokiem ewangelicznym” i prowadzona w języku przystosowanym do czasu i osób (zob. EN 54) ${ }^{1}$. Z kolei Jan Paweł II, autor określenia „nowa ewangelizacja”, wiele razy wypowiada się w kwestii odnowienia działalności pastoralnej tak, by nawiązać rzeczywistą więź z odbiorcą przepowiadania zbawczego ${ }^{2}$. Wymogiem zwrotu antropologicznego jednak według niego jest, „aby ośrodkiem nowej ewangelizacji było spotkanie z żywą osobą Chrystusa” (EA 57). Można tu dostrzec wskazanie na żywotność chalcedońskiego orzeczenia, które pozwala rozumieć obecność transcendentnego Boga w ludzkiej egzystencji; poprzez wcielenie Bóg staje się obecny i aktualny dla każdego człowieka: „Syn Boży przez wcielenie swoje zjednoczył się jakoś z każdym człowiekiem" (EV 2, por. RH 8). W tym kontekście należy odczytać słowa papieża o katechezie: „Najcenniejszym darem, jaki Kościół może dać dzisiejszemu zagubionemu i niepokojem trawionemu światu, to ukształtować w nim chrześcijan, utwierdzonych w tym, co istotne i radujących się w pokorze swoją wiarą. Tego właśnie uczy ich katecheza i ona

\footnotetext{
1 Warto zauważyć, że Paweł VI zwraca uwagę na „bardzo wielką liczbę ochrzczonych, którzy po większej części nie wyrzekli się wyraźnie swego chrztu, ale pozostają jakby na marginesie i nie żyją według niego" (EN 56). Obojętność wobec własnego chrztu stanowi realną przeszkodę, co domaga się działania ewangelizacyjnego. Remedium, o którym wspomina papież, może być rozwój małych wspólnot, „wspólnot zaczątkowych” (zob. EN 58).

2 Zob. Jan Paweł II, II Synod Biskupów poświęcony Europie. Rozważanie przed modlitwa Anioł Pański, „L’Osservatore Romano” 9(1996), s. 26.
} 
pierwsza dzięki temu się rozwija" (CT 61). Benedykt XVI swoje nauczanie kieruje wprost do świata, który żyje tak, jakby Boga w nim nie było, i który zadowala się religijnością powierzchowną/pogańską, niedającą żadnych odpowiedzi na pytania współczesnego człowieka. Dlatego papież często wraca do katechezy patrystycznej, ukazując chrześcijańską antropologię jako przejaw zainteresowania Boga ludzką historią ${ }^{3}$. Wreszcie Franciszek, chyba najbardziej z ostatnich papieży skupia się na samych warunkach głoszenia Ewangelii w dzisiejszych czasach, otwierając szereg dyskusji na najbardziej wrażliwe kwestie współczesnego świata. Nowe dyrektorium katechetyczne, podejmując niektóre z tych pytań, ukazuje też nieco inaczej odbiorców procesu ewangelizacji/katechezy.

W niniejszym artykule przyjrzymy się tym nowym/starym adresatom. Analizując zapisy Dyrektorium o katechizacji - w ich integralnym odniesieniu do rozumienia współczesnego człowieka, odbiorcy katechezy, ale też szerzej: ewangelizacji - uwzględnimy podwójną perspektywę myślenia o adresacie: wpierw odwołamy się do kryterium ilościowego, wyszczególniając poszczególne grupy społeczne i eklezjalne, następnie do kryterium jakościowego, wskazując na odbiorców pod kątem możliwości ich zaangażowania w rozwój wiary czy etapu wtajemniczenia. Wydaje się, że autorzy dokumentu świadomi są złożoności sytuacji, w jakiej dokonuje się dzisiaj dzieło głoszenia Dobrej Nowiny, choć - jak to zazwyczaj dzieje się w przypadku dokumentów - nie rozwiązują szeregu kwestii, istotnych z punktu widzenia organizacji pracy duszpasterskiej czy katechetycznej. Takie kwestie zostawia się praktyce pastoralnej. Poniższa analiza dotyczy sposobu ujęcia adresatów katechezy w Dyrektorium, co wymaga porównania choćby z wcześniejszym Dyrektorium w odniesieniu do badanej kwestii czy odwołania do innych ważnych dokumentów Kościoła (zwłaszcza papieża Franciszka), które mogą lepiej scharakteryzować tych adresatów. Warto przy tym pamiętać, że - jak pisze Andrzej Kiciński - „ukazanie się trzeciego Dyrektorium o Katechizacji rozpoczyna kolejny etap odnowy, jaka dokonuje się w katechezie i z pewnością jest nowym impulsem dla rozwoju myśli i praktyki katechetycznej"4. Poniżej poszukamy odpowiedzi na pytanie, czy rzeczywiście nowy dokument jest w stanie stać się takim impulsem odnowy w odniesieniu do rozumienia nowych adresatów katechezy ${ }^{5}$.

\footnotetext{
3 Zob. Benedykt XVI, Katechezy o Ojcach Kościoła, Kraków 2008.

4 A. Kiciński, Rozwój dyrektoriów katechetycznych po Soborze Watykańskim II (1971 - 1997 - 2020), „Roczniki Teologiczne” 11(2020), s. 26.

5 Radosław Mazur twierdzi, że byłoby „lepiej mówić o uczestnikach katechezy niż o adresatach, ponieważ w procesie katechetycznym każdy ma do spełnienia określone zadania i wpływa na kształt katechezy”. R. Mazur, Nowi adresaci katechezy?, „Studia Katechetyczne” 10(2014), s. 191.
} 


\section{Nowa sytuacja katechezy}

Katecheza jest dziełem Kościoła, dlatego zależy od jego aktualnej postaci czy sposobu wcielania się w konkretne kultury. Przyjmując wzorzec pierwotnego Kościoła, zawsze myślimy o pewnych podstawowych zasadach, jak choćby pierwszeństwie kerygmatu przed dogmatem czy inicjacyjnym charakterze katechezy. Ze względu na początek, sytuacja antycznego Kościoła była specyficzna, jednak w tradycji rozwoju katechezy otrzymaliśmy bogactwo doświadczenia, które stanowi źródło naszej motywacji i dalszej refleksji. Przez wieki Kościół z różnym powodzeniem wychodził naprzeciw sytuacji kolejnych pokoleń, obecnie żyjemy w perspektywie kształtowania się Kościoła jako wspólnoty misyjnej. Według papieża Franciszka, aby nie stracić ducha pierwszych chrześcijan, a zarazem odpowiedzieć na sytuację zagubienia współczesnego człowieka, należy postawić Kościół w „permanentny stan misyjny" (EG 25) ${ }^{6}$. Franciszek utożsamia Kościół ze wspólnotą misyjną: „Misyjny zapał jest wyraźnym znakiem dojrzałości wspólnoty kościelnej” (Orędzie na Światowy Dzień Młodzieży 2013, nr 1); bez misyjnego zaangażowania Kościół utraci swą żywotność i wiarygodność (EG 27; por TMA 57). Wynika to z faktu, że misyjność Kościoła (według Dyrektorium z 1997 r. rozumiana bardziej jako zadanie katechezy, w nowym Dyrektorium stanowiąca o całości oddziaływania Kościoła) wpisana jest w tchnienie Jezusa, posyłającego uczniów do świata (zob. Mk 16,15). Papież wielokrotnie wzywał chrześcijan do zaangażowania się w działalność misyjną; np. do młodzieży mówił: „Musicie nauczyć się Jezusowego stylu działania, czyli przepowiadania, dawania świadectwa, pielęgnowania kontaktów z ludźmi i utożsamiania się ze swoją misją"7. W istocie chodzi tu o wezwanie do odnowy kerygmatycznej oraz uwrażliwienie na inicjacyjny oraz inkulturacyjny charakter ewangelizacji (i katechezy ${ }^{8}$ ). Katecheza nabiera więc dzisiaj znaczenia jako „dzieło misyjnego wychodzenia” (DK 49), co oznacza, że ma ona „zbliżyć się do współczesnych ludzi, krocząc przy ich boku, gdziekolwiek się znajdują" (DK 50). Kościół jest już nie tylko wspólnotą - a nawet wspólnotą wspólnot - można powiedzieć, że Kościól jest wspólnota $w$ drodze ${ }^{9}$, a katecheza towarzyszeniem wspólnoty każdemu, kto znajduje się w drodze, lecz także tylko przygląda się tej drodze (ów

\footnotetext{
6 „Działalność misyjna stanowi paradygmat każdego dzieła Kościoła”. EG 15.

7 Franciszek, Bądźcie uczniami i misjonarzami Chrystusa. Wystąpienie papieża podczas Liturgii Słowa Święta Powitania 28. Światowych Dni Młodzieży, Rio de Janeiro, 25 lipca 2013, „Wiadomości KAI” 31(2013), s. 14.

8 Choć katecheza stanowi istotny moment procesu ewangelizacji, ze względu na misyjne zaangażowanie chrześcijan wyraźnie traci na ostrości obowiązujący dotąd podział na etapy głoszenia wiary: missio ad gentes - preewangelizacja - ewangelizacja - katecheza - stała formacja w wierze. Katecheza na każdym etapie bowiem może oznaczać pogłębienie wiary. Zob. DK 55-60.

9 Franciszkowe „Kościół wyruszający w drogę” (EG 20) można rozumieć także jako wskazanie na nieustanną potrzebę odnowy, wezwanie do rzeczywistego przejścia procesu rozeznania, oczyszczenia i przemiany. Por. Jan Paweł II, EiO 19.
} 
drugi przypadek chyba nawet jest częstszy, biorąc pod uwagę brak rzeczywistego wtajemniczenia współczesnego chrześcijanina w pogłębienie świadomości chrztu).

W sytuacji wezwania do „nawrócenia pastoralnego” (zob. EG 25-33) papież wskazuje na długi i niełatwy proces odnowy Kościoła, zmierzający do wewnętrznej przemiany i komunii $z$ Chrystusem. $\mathrm{W}$ istocie $\mathrm{w}$ tym procesie katecheza znajduje swą ważną i niezbędną pozycję, będąc nie tylko systematycznym wykładem wiary, lecz ze względu na aspekt wtajemniczający i wychowawczy, w różny sposób i w różnej formie uczestnicząc w całości oddziaływania pastoralnego jako przygotowanie, pogłębienie (towarzyszenie) i włączenie katechizowanego w jego w codzienność, przenikniętą obecnością Boga. Takie poszerzone w stosunku choćby do definicji z Catechesi tradendae (zob. CT 18) rozumienie katechezy, modyfikuje też charakterystykę jej adresata. Katecheza bowiem sama w sobie staje się świadectwem nowego życia również wobec ludzi nieznających Ewangelii, niezdecydowanych, obojętnych, pasywnych czy chwiejnych religijnie ${ }^{10}$. $Z$ jednej strony zatem katecheza uczestniczy w procesie zaplanowanego działania formacyjnego jako nieprzerwane traditio świadectw osób, które przeszły drogę przemiany, począwszy od czasów apostolskich (zob. LF 38), z drugiej strony dostarcza przestrzeni dla spotkania osób, które ze względu na współczesne prądy kulturowe - takie jak globalizacja, wirtualizacja czy sekularyzacja - sytuują siebie na obrzeżach drogi bądź deklarują się jako niezainteresowane droga, a dzięki różnym inicjatywom o znaczeniu katechetycznym (typu „dziedziniec pogan”, „rekolekcje dla zabieganych” czy „Taizé”) mają otwartą możliwość zarówno refleksji nad orędziem wiary, jak i stopniowej inicjacji w życie Boga. W ramach katechezy dorosłych można też mówić o tworzeniu doraźnych grup wsparcia, które ze względu na obciążające okoliczności życia (np. śmierć rodziców, utrata pracy czy problemy $z$ wychowaniem dzieci), organizują miejsce dla przepracowania problemów w świetle wiary, zapraszając także osoby nieidentyfikujące się z Kościołem, ale związane bezpośrednio z uczestnikami spotkań, którzy są wierzący ${ }^{11}$.

Reasumując ten wątek, sytuacja świata, wobec której nauczanie Kościoła przyjmuje postawę otwartej rozmowy, nie będącej w żadnym wypadku formą indoktrynacji ani wyższości, a więc postawę misyjnej (dziecięcej) radości - umożliwia katechezie wyjście naprzeciw nowym adresatom. To są ci sami odbiorcy, których charakteryzowały dotąd wydane dokumenty, jednak obecna sytuacja świata wskazuje, by bardziej konkretnie ich nazwać, wyodrębnić też bardziej szczegółowo poszczególne grupy adresatów, a przede wszystkim by w bardziej otwarty

\footnotetext{
10 Zob. Franciszek, Nawróćmy się na nowość Ewangelii, budujmy sieć solidarności. Homilia Franciszka wygłoszona podczas mszy św. z udziałem filipińskich biskupów, księży i osób konsekrowanych, Manila, 16 stycznia 2015, „Wiadomości KAI” 4(2015), s. 13-14; Franciszek, Kościół jest posłany, aby nieść Ewangelię całemu światu. Audiencja generalna, 16 października 2013, „Wiadomości KAI” 43(2013), s. 24-25.

11 Zob. D. Kurzydło, Formacja dorosłych $w$ dojrzałej wspólnocie chrześcijańskiej. Współczesna perspektywa, w: Problemy dorosłych ludzi. Formacja chrześcijańska dorosłych a codzienne trudności życia, D. Kurzydło (red.), Warszawa 2014, s. 13-20.
} 
sposób ukazać sposób wyjścia do nich. Katecheza, wpisana w nową wizję „Kościoła w drodze”, również dokonuje się w drodze: zgodnie z osobowością współczesnego człowieka, który ze względu na tempo życia z większym powodzeniem uczestniczy w formacji bardziej dynamicznej, towarzyszącej jego codziennej egzystencji (co pozwala mu dostrzegać znaczenie wiary w konkretnych realiach życia) czy zorientowanej na wartości bardziej niż na wiedzę. Katecheza świadoma nowych odbiorców jest więc bardziej wrażliwa na nieustannie zmieniającą się wokół nich rzeczywistość, świadoma ogromnej potrzeby budowania więzi między ludźmi, których oni są na ogół pozbawieni i zagospodarowywania nowych przestrzeni obecności w wymiarze społecznym (zob. LF 39).

Katecheza wychodzi zatem naprzeciw zarówno indywidualnym potrzebom współczesnego człowieka - towarzysząc mu w jego osobistej/wyjątkowej drodze zmagania się z samym sobą, jak również społecznym (często ukrytym) tęsknotom, wyrażającym pragnienie bycia kochanym, przyjętym, akceptowanym i docenianym - stając się promotorką życia wspólnotowego (angażującą do życia w małych, podstawowych wspólnotach) oraz wsparcia w trudnych okolicznościach życia. $\mathrm{W}$ istocie, takie podejście lepiej realizuje chrystocentryzm $\mathrm{w}$ katechezie niż w ramach hierarchicznego modelu parafii (zob. EG 48, 78) ${ }^{12}$. Franciszek motywuje: "Jest sprawą żywotną, aby Kościół, przyjmując wiernie wzór Mistrza, wychodził dzisiaj głosić Ewangelię wszystkim ludziom, w każdym miejscu, przy każdej okazji, nie zwlekając" (EG 23) ${ }^{13}$. Podłożem nowego spojrzenia na adresata jest więc nowy kontekst antropologiczny (dokonujące się procesy redefiniujące osobę ludzką i jej prawa) oraz nowy kontekst kulturowy (ściśle związany z poprzednim, dotyczący jednostronnie przebiegającego postępu technicznego, w tym rozwoju sztucznej inteligencji i komunikacji cyfrowej, uprzedmiotawiających człowieka). Owe konteksty wymuszają na Kościele i katechezie podjęcie adekwatnych kroków, zmierzających z jednej strony do pogłębienia formacji ludzkiej i chrześcijańskiej, z drugiej do uwiarygodnienia wymiaru religijnego człowieczeństwa. W tym sensie katecheza może być elementem szerszego procesu odnowy Kościoła i człowieka (zob. DK 1). Zorientowanie na człowieka czasu postmodernizmu oznacza wypracowanie na nowo katechezy kerygmatycznej i katechezy jako inicjacji mistagogicznej, co ma pozwolić na otwarcie wielu dróg egzystencjalnego dostępu do Tajemnicy i umożliwić doświadczenie żywej wspólnoty wiary (zob. DK 2).

12 Zob. Nawrócenie duszpasterskie wspólnoty parafialnej w służbie misji ewangelizacyjnej Kościoła, Wrocław 2020, nr 27-41.

13 Franciszek wiele razy stawiał diagnozę dotyczącą kondycji Kościoła, który uważa za schorowany (miarą choroby jest symboliczna rezygnacja Benedykta XVI, a potem jego dziełko List o przyczynach kryzysu Kościoła, Kraków 2019). Franciszek uważa też, że dotychczasowe struktury kościelne mogą być mało adekwatne względem nowych wyzwań i nowych form działań (zob. EG 26, 33). Papież bardzo poważnie i dalekosiężnie spogląda na tę sytuację, proponując prawdziwą "pobudkę" duszpasterską. Zob. Bez Kościoła nie możemy być zbawieni. Audiencja generalna, 25 czerwca 2014, „Wiadomości KAI” 27-28(2014), s. 37. 


\section{Katecheza w życiu ludzi}

Tak zatytułowany jest siódmy rozdział nowego Dyrektorium, gdzie wskazuje się na prawo każdego ochrzczonego do odpowiedniej katechezy, prowadzącej do dojrzałej wiary (zob. DOK, 167; DK 224). Ten ochrzczony nie jest już anonimowym człowiekiem, ale rzeczywistą, konkretną, historyczną, zanurzoną w określonej sytuacji osobą, charakteryzującą się własną dynamiką psychologiczną, społeczną, kulturową i religijną (zob. DK 224). Spójrzmy najpierw na adresata w kluczu socjologicznym, tzn. jako na członka określonej grupy, do której jest adresowana katecheza. W porównaniu z poprzednim Dyrektorium ${ }^{14}$, gdzie wyodrębniono adresatów katechezy względem kilku kryteriów (wieku, specyficzności sytuacji osobowościowej, kontekstu społeczno-religijnego oraz kontekstu społeczno-kulturowego), w nowym dokumencie ograniczono się ogólnie do wyszczególnienia grup (dołączając nowych adresatów), do których skierowana jest działalność katechetyczna. W DOK informacja o adresatach jest bardziej rozbudowana, wielostronna i ukazana w różnych dynamicznych kontekstach, w DK próbuje się widzieć odbiorców w ramach określonej zamkniętej społeczności, całą różnorodność oddziaływania opierając na uprzednim ukazaniu procesu ewangelizacji w złożonym kontekście współczesności. Z tego względu nie można więc powiedzieć, że charakterystyka nowego dokumentu jest uboższa, jest inna - inaczej rozłożono akcenty, podkreślając znaczenie przyjęcia odpowiedniej postawy wobec różnych grup społecznych. $Z$ tego powodu może nawet wydawać się bardziej czytelna. Trzeba przyznać, że w zasadzie samo rozumienie adresata i uwzględnienie inkulturacji wiary jest podobne. Tymczasem w nowym dokumencie wprowadza się inną kolejność odbiorców ${ }^{15}$ (przyjmując, że kolejność umieszczenia ich $w$ dokumencie jest nie bez znaczenia): najpierw jest katecheza rodzinna (nieobecna w taki sposób w starym dyrektorium), następnie katecheza: z dziećmi, młodzieżą, dorosłymi, osobami starszymi ${ }^{16}$. Dodatkowo osobne miejsce wśród adresatów posiadają jeszcze niepełnosprawni, imigranci, emigranci, osoby zmarginalizowane (znajdujące się w więzieniach). Byłoby nadużyciem mówić w tym przypadku o nowości adresatów, ponieważ w DOK (zob. nr 189-192) również wymienia się osoby niepełnosprawne i nieprzystosowane (wspomina się tu o objęciu

14 O ile nie zachodzi istotna rozbieżność z dokumentem z roku 1997, nie przywołujemy w niniejszej analizie Ogólnej instrukcji katechetycznej z 1971 r.

15 Była ona odwrócona w DOK, gdzie na pierwszym miejscu wskazano katechezę dorosłych - jako najważniejszą formę katechezy (por. CT 43). W OIK najpierw omówiono katechezę dzieci. Należy zaznaczyć, że w najstarszym dyrektorium rozumienie adresatów jest najwęższe (dotyczy tylko wieku); w kolejnych dyrektoriach następuje coraz gruntowniejsze poszerzenie rozumienia terminu „adresaci”.

16 Warto zaznaczyć, że w DK nie używa się pojęć takich jak „katecheza dorosłych” czy „katecheza młodzieży”, lecz wprowadzając spójnik „z" mowa jest o katechezie z dorosłymi, katechezie z młodzieżą itd. W przypadku rodziny mamy aż trzy sytuacje: katecheza „w rodzinie”, „z rodziną” oraz „rodziny”. 
opieką rodziny takich osób), emigrantów, uciekinierów, nomadów, bezdomnych, chronicznie chorych, uzależnionych, więźniów, przedstawicieli świata pracy, wolnych zawodów, artystów, ludzi nauki, studentów, mieszkańców wsi. Natomiast w DK (zob. nr 273-282) więcej miejsca poświęca się jedynie imigrantom, emigrantom oraz osobom zmarginalizowanym (odnajdujemy tu cenne informacje w związku z katechezą wśród takich ludzi); wśród grupy osób zmarginalizowanych wymienia się uchodźców, nomadów, bezdomnych, przewlekle chorych, więźniów, i dodaje (czego nie było w DOK): narkomanów oraz osoby zniewolone przez prostytucję. Nowy akcent został w tak wyrazisty sposób położony na rodzinie: katecheza z rodziną dla twórców nowego Dyrektorium jest pierwszorzędną formą katechezy, która w różnorakiej formie i postaci wyprzedza każdą inną. W Dyrektorium z 1997 r. myśli się podobnie, ale nie znalazło to jeszcze tak klarownego odbicia w strukturze dokumentu. Ogólnie można uznać, że nie ma większej różnicy w postrzeganiu samego adresata między oboma dokumentami; jedynie w przypadku niektórych grup znajdujemy szerszy opis katechezy. Ponieważ zawsze wynikało to z przekonania Kościoła, iż odbiorcą katechezy jest każdy człowiek, zwłaszcza ochrzczony, Autorzy nowego Dyrektorium dostosowują się do aktualnej sytuacji kulturowo-społecznej oraz zagrożeń, jakie ona z sobą niesie ${ }^{17}$.

W starym Dyrektorium zaakcentowano fakt, iż „konieczne zwrócenie uwagi na różne sytuacje życiowe ludzi skłania katechezę do wykorzystania różnych sposobów, aby spotkać się z nimi i dostosować orędzie chrześcijańskie oraz pedagogię wiary do różnych wymagań" (DOK 165). Toteż kryterium wieku, choć najobszerniej omówione, pozostaje umieszczone obok (a może pośród) innych zmiennych, wskazujących na zróżnicowanie sytuacji odbiorców. Zwraca się tam uwagę, że istotne w tej kwestii pozostają także wyniki badań współczesnych nauk o człowieku (pedagogiki, psychologii, socjologii) ${ }^{18}$. W nowym Dyrektorium - jak już zaznaczyliśmy - wskazuje się nieco mocniej na konkretnego odbiorcę, nakazując uwzględnienie jego sytuacji pod każdym możliwym aspektem (zob. DK 225). Autorzy Dyrektorium odsyłają w tym miejscu do danych antropologiczno-ewolucyjnych i teologiczno-duszpasterskich, nie podają jednak żadnych kryteriów, które pozwoliłyby umieścić katechezę w złożonym kontekście uwarunkowań społeczno-kulturowych. W rozdziale poświęconym adresatom pomija się w tym miejscu odniesienia do innej przesłanki niż kategoria wieku. Szerzej patrzy się na adresatów katechezy w części zatytułowanej „Katechizacja w Kościołach partykularnych”, co pokazuje, że Autorzy Dyrektorium konsekwentnie dążą do tego, by umieścić odbiorców w konkretnym środowisku kulturowym i eklezjalnym. Zanim do tego wrócimy, warto przypomnieć

\footnotetext{
17 Zob. J. Ihnatowicz, Adresaci katechezy. Omówienie IV części Dyrektorium Ogólnego o Katechizacji, „Katecheta” 6-7(1998), s. 32. W Dyrektorium z 1997, podobnie jak w Catechesi tradandae (nr 35) mówi się, że „Wszyscy potrzebują katechizacji”.

18 Zob. J. Misiewicz, Adresaci katechezy wedtug Dyrektorium ogólnego o katechizacji, w: I. Dec (red.), Kościół katechizujący i katechizowany, Wrocław 2003, s. 164.
} 
kwestie, które zauważył już Jan Paweł II w encyklice Redemptoris missio, a na którą - obok adhortacji Benedykta XVI Verbum Domini - powołuje się w tym miejscu dokument. Encyklika ta jest o tyle ważna, że mocno koresponduje z wysuniętym przez dokument na pierwszy plan wymiarem misyjnym Kościoła/katechezy. Otóż Jan Paweł II wskazuje na nowe zjawiska społeczne, takie jak „urbanizacja, masowe migracje, przemieszczanie się uchodźców, dechrystianizacja krajów od dawna chrześcijańskich, zaznaczający się wpływ Ewangelii i wartości ewangelicznych w krajach o znacznej większości niechrześcijańskiej, ale też mnożenie się mesjanizmów i sekt religijnych" (RM 32). Zjawiska te odsłaniają nowe grupy adresatów katechezy: nie chodzi przy tym najbardziej o niewierzących - do nich wszak kierowana jest missio ad gentes - ale o chrześcijan, którzy żyją pośrodku nowej rzeczywistości i potrzebują efektywnego wsparcia ze strony Kościoła. Jan Paweł II przywołuje jeszcze inne współczesne areopagi, w których dzieło katechezy coraz bardziej staje się niezbędne: za najważniejszy uznaje świat środków społecznego przekazu, „który jednoczy ludzkość i czyni z niej, jak to się określa, światowa wioskę" (RM 37). Massmedia osiągnęły tak ogromne znaczenie w życiu ludzi, że „są głównym narzędziem informacyjnym, formacyjnym, przewodnikiem i natchnieniem w zachowaniach indywidualnych, rodzinnych, społecznych" (tamże $)^{19}$. Jeszcze szerzej patrząc, chodzi w ogóle o ludzką kulturę, która jako owoc określonego stylu życia (obecnie określanego mianem ludycznego ${ }^{20}$ ) stała się terenem pierwszej ewangelizacji, ale też katechezy. Jak proroczo zauważył polski papież, nie chodzi o to, by ewangelizować współczesną kulturę, szerząc naukę chrześcijańską, ale „włączyć samo orędzie w tę nową kulturę, stworzoną przez nowoczesne środki przekazu" (RM 37, por. TMA 57, EiE 58-60). Do tego areopagu kultury Jan Paweł II dolicza też naukowców, instytucje międzynarodowe działające na rzecz pokoju, rozwoju i wyzwolenia ludów, a także ochrony przyrody, wreszcie kobiety i dzieci oraz młodzież (zob. RM 37) ${ }^{21}$.

Dyrektorium z 2020 r. jest świadome tych wszystkich wyzwań; wskazuje, że katecheza służy inkulturacji wiary, ma bowiem sobie właściwy wymiar kulturowy i społeczny (zob. DK 319). Prowadzenie dzieła katechizacji powinno według Autorów dokumentu zaczynać się od uświadomienia sobie sytuacji pluralizmu i złożoności, co pozwala zrozumieć, z jakim człowiekiem spotykamy się w procesie zbawienia (zob. DK 320-342). Nie wystarczy jednak założyć tylko, że wśród dorosłych, do których jest kierowana katecheza, znajdują się trzy grupy wierzących: ci, którzy pragną pogłębienia swojej wiary; ci, którzy oddalili się od wiary (ze względu

\footnotetext{
19 W dokumencie Aetatis novae (nr 19) Kościół zwraca uwagę na potrzebę duszpasterstwa osób pracujących w mediach.

20 Zob. A. Kłocińska, Karnawał wobec sacrum. O ludyczności kultury współczesnej, „Kultura i Wartości" 3(2012), s. 117-134. Zjawisko urbanizacji sprawia, że wielkie miasta stały się uprzywilejowanymi miejscami dla duszpasterstwa; to tutaj powstają "nowe zwyczaje, i wzorce życiowe, nowe formy kultury i wzajemnych odniesień, które wywierają wpływ na ludność". RM 37.

21 Zob. T. Kopiczko, Nowe fora katechezy, „Studia Katechetyczne” 13(2017), s. 175-187; G. Wita, Areopagi nowej ewangelizacji, „Studia Salvatoriana Polonica” 6(2012), s. 91-106.
} 
na słabą formację); ci, którzy, nie przyjęli dotąd chrztu (zob. DOK 172, DK $258^{22}$ ). Trzeba uchwycić cały „wielościenny charakter” (DK 321, EG 236), wskazujący na niejednorodną i zmienną rzeczywistość istniejącą w każdym człowieku, uwikłanym w codzienne wielorakie relacje zawodowe, rodzinne, towarzyskie, medialne, społeczne itp. Dyrektorium wskazuje na umiejętność interpretacji pozwalającej widzieć daną sytuację i danego człowieka z różnych perspektyw, pozostając zarazem świadomym ich współzależności (zob. DK 321). To samo dotyczy młodzieży, która przeżywa bardzo specyficzny zwrot w swoim życiu, próbując (bądź nie) zrozumieć własną tożsamość w obliczu wielu wykluczających się postaw aksjologicznych i kulturowych. „Ważne - czytamy w Dyrektorium - by Kościół, który pragnie każdemu człowiekowi ofiarować piękno wiary, był świadom tej złożoności i wypracował pogłębione i bardziej światłe spojrzenie na rzeczywistość" (DK 321). Uściślając jeszcze bardziej, mowa jest dalej o różnych kontekstach, w jakich dzisiaj - również ze względu na łatwy dostęp do świata wirtualnego - żyje człowiek: a więc o środowisku ekumenicznym i wieloreligijnym, o mentalności społeczeństwa sieciowego (informatycznego) czy o kontekście dużych aglomeracji i tradycjach lokalnych. Oprócz areopagów wspomnianych przez Jana Pawła II, dodaje się jeszcze przestrzenie czasu wolnego, rozrywki, turystyki, muzyki i rozmaitych działań artystycznych (zob. DK 324). Stosunkowo wiele miejsca poświęca się zjawiskom urbanizacji (kontekst miejski), ekologizacji (kontekst wiejski), tradycyjnym kulturom lokalnym (w sensie pozytywnym) oraz pobożności ludowej (jako ważnemu miejscu teologicznemu). Katecheza w obliczu tej różnorodności odbiorcy staje się krzewicielką „piękna wielokształtnego oblicza” (DK 334, por. EG 116, NMI 295). Bardzo rozbudowany jest także wątek poświęcony katechezie chrześcijan, żyjących w warunkach ekumenizmu i pluralizmu religijnego (zob. DK 343-353). Autorzy nowego Dyrektorium nie zaniedbali obecności katechezy ani w środowisku nauki (zob. DK 354-358 oraz 373-380), ani w przestrzeni kultury cyfrowej (zob. DK 359-372), ani wobec kwestii ekologii (zob. DK 381-384). Ze względu na opcję preferencyjną obecnego pontyfikatu, wiele miejsca pozostawia się także ludziom ubogim (zob. DK 385-388), a przywołując społeczną naukę Kościoła, wskazuje się na obecność katechezy w środowiskach pracy oraz działalności społecznej (zob. DK 389-393). Ponieważ prawo do katechezy ma każdy ochrzczony, próbuje się coraz bardziej nazywać te miejsca, w których warto podjąć katechezę wrażliwą na specyficznego odbiorcę. Wydaje się, że w tę właśnie stronę następuje poszerzenie spojrzenia, związane z adresatem katechezy: odejść od modelu organizowania katechezy jako systematycznego wykładu prawd wiary (co nie oznacza rezygnacji z myślenia o katechezie także w ten sposób), aby podjąć model wychodzenia ku

\footnotetext{
${ }^{22}$ Nowe Dyrektorium poszerza tę grupę do sześciu kategorii (zob. DOK 258); wymienia się też tych, którzy nie żyją wiarą, ale szukają kontaktu ze wspólnotą w szczególnych momentach życia; tych, którzy wywodzą się z innych wyznań chrześcijańskich lub innych doświadczeń religijnych; tych, którzy powracają po epizodach w nowych ruchach religijnych.
} 
różnym środowiskom, ludziom - chrześcijanom żyjącym w rozmaitych środowiskach i w obliczu różnych wpływów kulturowych. Adresatem jest każdy człowiek ochrzczony - lub nieochrzczony, jeśli przygotowuje się do chrztu - odnaleziony w miejscu swojego bytowania i zmagania się z własną tożsamością chrześcijanina i grzesznika. Nowość podejścia do adresata w tym kontekście dobrze wyraża myśl Franciszka zapisana w Evangelii gaudium: „Za każdym razem, gdy staramy się powrócić do źródeł i odzyskać pierwotną świeżość Ewangelii, pojawiają się nowe drogi, twórcze metody, inne formy wyrazu, bardziej wymowne znaki, słowa zawierające nowy sens dla dzisiejszego świata" (EG 11).

\section{Katecheza w rozwoju wiary}

Drugie kryterium dotyczące adresata katechezy dotyczy procesu wtajemniczenia $\mathrm{w}$ doświadczenie wiary oraz towarzyszenia mu w dążeniu do stawania się dojrzałym chrześcijaninem. To kryterium jakościowe. O ile bowiem wyżej identyfikowaliśmy poszczególne grupy, do których kierowana jest katecheza, teraz chcemy skupić się na konkretnym adresacie, który ma prawo otrzymać wszystkie środki niezbędne $\mathrm{w}$ procesie dojrzewania wiary: pedagogia wiary wymaga przeprowadzenia powołanego przez cały proces inicjacji chrześcijańskiej w taki sposób, aby był on w stanie odkryć w sobie nowe życie. Dyrektorium z 2020 r. w tym celu zwraca uwagę, jeszcze bardziej niż wcześniejsze dyrektoria, na inspirujący charakter katechumenatu (zob. DK 61-65). O potrzebie odnowy Kościoła poprzez katechumenalny charakter formacji mówił już II Sobór Watykański (zob. DM 14, KL 64-66, DB 14). Joseph Ratzinger zauważył, że chrześcijaństwa nie wymyślono przy biurku, ale zrodziło się ono z głębokiego doświadczenia Boga. Dlatego według niego „tym, czego przede wszystkim potrzebujemy, jest odbudowa życiowego kontekstu katechumenalnego wprowadzania w wiarę jako miejsca wspólnego doświadczenia Ducha, które dzięki temu może stać się podstawą nasyconej rzeczywistością refleksji”"23. W tym duchu, proces inicjacji nie ogranicza się do samego tylko przygotowania do przyjęcia sakramentów świętych, ale jest prawdziwym uczestnictwem w wierze, które w konkretnym momencie się zaczyna i będzie trwać przez całe życie. Katecheza staje się więc naturalnym "towarzyszem” życia chrześcijańskiego. Dyrektorium, wskazując na kerygmatyczną naturę katechezy, zaraz obok umieszcza katechumenat, wskazując na jego charakter formacji wieloetapowej, długotrwałej, wspólnotowej, integralnej i liturgicznej. Autorzy dokumentu zaznaczają jednak, że „katechumenalna inspiracja katechezy nie oznacza ślepego naśladowania katechumenatu, lecz przyjęcie właściwego mu stylu i dynamizmu formacyjnego" (DK 64).

\footnotetext{
${ }^{23}$ J. Ratzinger, Co jest konstytutywne dla wiary chrześcijańskiej dzisiaj, w: „Opera Omnia” 9(2018)1, Lublin, s. 64. Ratzinger uważa, że „nauczanie chrześcijańskie powstało najpierw w kontekście katechumenatu i tylko w tym kontekście można je odnowić” (tamże, s. 65).
} 
Mirosław Gogolik zauważa, że jeśli katechumenat ma stanowić inspirację dla współczesnej katechezy, sprawą podstawową jest „docenienie i uwrażliwienie duszpasterzy i wiernych na znaczenie funkcji wtajemniczającej katechezy przygotowującej do chrztu" 24 (i innych sakramentów inicjacji chrześcijańskiej). Brak tej wrażliwości chyba najbardziej wpływał dotąd na słabe zaangażowanie w katechezę - zarówno wiernych, którzy nie dostrzegają potrzeby pogłębiania wiary, skoro otrzymali niezbędne minimum kwalifikujące ich do uzyskania zgody na dopuszczenie do przyjęcia kolejnego sakramentu, jak również duszpasterzy, którzy nierzadko akceptują taką sytuację, nie rozumiejąc znaczenia katechumenalnego przygotowania do sakramentów (zob. EG 76-109). To z tego powodu linią przewodnią odnowy parafii jest „nawrócenie pastoralne” i „nawrócenie misyjne” (zob. EG 25-33; DK $40)^{25}$. W Dyrektorium mówi się w tym kontekście o „dynamice relacyjnej”, która ma prowadzić do modelu parafii jako wspólnoty wspólnot (zob. DK 301) ${ }^{26}$. Adresatem katechezy w tym modelu nie jest ekspert ani elita ludzi „dobrze poinformowanych", ale uczeń-misjonarz: człowiek, który ma doświadczenie zmartwychwstałego Chrystusa i potrafi w Jego Duchu budować nowe relacje z innymi. Mimo własnych słabości i niedostatecznych zasobów, jest on zdolny do rozszerzania rzeczywistego braterstwa jako znaku obecności Chrystusa w Jego Kościele na ziemi (zob. DK 303). Stąd wynika także najbardziej skuteczny model ewangelizacji (nowej ewangelizacji), która dokonuje się „od osoby do osoby” (podczas zwykłego spotkania, rozmowy, na ulicy czy w pracy) (zob. EG 127). Takie proste katechezy, które potrafi głosić każdy głęboko nawrócony, sprawiają, że rozumienie adresata radykalnie się zmienia, czyniąc nim każdego potencjalnego słuchacza i świadka czyjegoś nawrócenia i opowieści o relacji z Chrystusem. I choć w tym przypadku, ściśle rzecz biorąc, możemy mówić jedynie o pre-katechezie, znacznemu poszerzeniu ulega rozumienie odbiorcy, którego należy postrzegać jako zawsze znajdującego $w$ drodze (zob. DK 50).

Franciszek zaleca, by „z miłosierdziem i cierpliwością towarzyszyć możliwym etapom wzrastania osób formujących się dzień po dniu" (EG 44, por. FC 123). Człowiek na każdym etapie, od chwili gdy jeszcze nie jest objęty opieką duszpasterską aż po etap starzenia się, jest w stanie czerpać - choć w różnym stopniu, na miarę potrzeb i możliwości - z katechezy, którą głosi się w różnej formie ${ }^{27}$. Jest to jednak możliwe jedynie wówczas, gdy zasadą życia i działania Kościoła jest koinonia ${ }^{28}$.

\footnotetext{
${ }^{24}$ M. Gogolik, Katecheza parafialna dorosłych $w$ kontekście nowej ewangelizacji, „Katecheza” (11)2013, s. 88.

25 Zob. Nawrócenie duszpasterskie wspólnoty parafialnej, nr 3-26.

26 Zob. tamże, nr 27-33.

${ }^{27}$ W Dyrektorium z roku 1997 wskazuje się w tym kontekście na różne kategorie ochrzczonych, którzy nie przeżyli jeszcze prawdziwego wtajemniczenia w wierze (nie są więc świadomi swojej wiary) ze względu na wpływ współczesnych prądów kulturowych. Są wśród nich: niepraktykujący, wykształceni z wiarą na poziomie dzieciństwa, ukrywający swą chrześcijańską tożsamość. Zob. DOK 25-26.

28 Zob. F. Blachnicki, Istotne cechy ruchu eklezjalnego, Kraków 2018, s. 31-40.
} 
Z jednej strony Kościół jest więc świadomy wyraźnej opozycji między zmieniającą się rzeczy wistością a szukającym wewnętrznego oparcia człowiekiem, co nakazuje podnieść jakość katechezy adresowanej do współczesnego odbiorcy żyjącego w niestabilnym świecie, $\mathrm{z}$ drugiej inspiracja katechumenatem - zawierającym $\mathrm{w}$ sobie wszystkie elementy niezbędne w procesie wtajemniczenia i mistagogii - jest wyjściem poza ograniczenia, jakie stworzyło przeniesienie „katechezy” do szkoły, co niestety znacznie osłabiło świadomość potrzeby pogłębiania daru chrztu na drodze rozeznawania i oczyszczania wiary. Dlatego w Dyrektorium (zresztą nie tylko w tym nowym) tyle miejsca poświęca się katechezie chrześcijańskiego wtajemniczenia, skutecznej ze względu na podstawowość, organiczność, systematyczność (procesualność) i integralność formacji (zob. DK 71). Właśnie te cechy katechezy wtajemniczającej - co przypomina nowy dokument - gwarantują, że adresat katechezy będzie żył wiarą wyznawaną, celebrowaną, przeżywaną i przemodloną (zob. DK 72). W odniesieniu do formacji stałej, wymagającej obecności liturgii (świadomości „my”), należałoby położyć większy nacisk na uczestnictwo w całym jej bogactwie obecnym także w Liturgii Godzin oraz w praktyce lectio divina.

W tym miejscu warto zwrócić uwagę na adresata/adresatów, jakimi są stowarzyszenia, ruchy i grupy wiernych. To w ich łonie dokonuje się najczęściej prawdziwa praktyka dojrzewania wiary, niektóre z nich przyjmują mniej lub bardziej model katechumenalny formacji chrześcijańskiej. Dyrektorium mówi o nich, że „charakteryzują się wielką zdolnością do ewangelizacji” i są „źródłem odnowy i apostolstwa” (DK 304). Przywołuje się tu także podstawowe wspólnoty kościelne (zob. DK 306), które są „znakiem żywotności Kościoła, narzędziem formacji i ewangelizacji, ważnym punktem wyjścia dla nowego społeczeństwa zbudowanego na fundamencie cywilizacji miłości [..], jeśli naprawdę żyją w jedności z Kościołem, są prawdziwym wyrazem komunii i narzędziem budowania jej w postaci bardziej pogłębionej" (RM 51, por. EN 58 ${ }^{29}$. Wspólnoty takie i grupy eklezjalne stanowią naturalne miejsce zaangażowania ludzi „w sposób bardziej całościowy” (DK 308) i sprzyjają konsekwentnemu dążeniu do uczestniczenia w dojrzewaniu wiary oraz trosce o relacje międzyludzkie. Są też najlepszą przestrzenią dla inkulturacji wiary: tu przekłada się orędzie ewangeliczne na język zrozumiały dla konkretnych uczestników procesu formacji i ubogaca nowymi formami wyrazu (zob. DK 394-395). Dzięki wrastaniu Ewangelii w kulturę określonej społeczności, jej codzienne życie, dokonuje się wysiłek słuchania (usłyszenia głosu Boga w warunkach zwykłej ludzkiej egzystencji), rozróżniania tego, co autentyczne, oczyszczania tego, co naznaczone grzechem,

\footnotetext{
29 Wartość tego zapisu tkwi również w jego odniesieniu do chaosu aksjologicznego współczesnego świata. Janusz Chyła pisze: „Człowiek potrzebuje integralnego spojrzenia na siebie i świat, swoją przeszłość i nadzieje na przyszłość, potrzebuje intelektualnego i egzystencjalnego ogarnięcia całości. Taką możliwość daje Ewangelia i wynikająca z niej antropologia. Potrzeba zatem odpowiedniej formacji do krytycznego spotkania z natłokiem informacji”. J. Chyła, Ewangelizacja cyfrowego kontynentu, „Kultura - Media - Teologia” 22(2015), s. 72.
} 
stymulowania postaw sprzyjających nawróceniu serca oraz cierpliwego dojrzewania wewnętrznego (zob. DK 398, DOK 204).

Patrząc na całość dokumentu, można odnieść wrażenie, że jego Autorzy patrzą na adresata katechezy od samego początku w kontekście jego formacji nie w oderwaniu od złożonej rzeczywistości świata, ale dokładnie pośrodku niej w codziennym kroczeniu za Chrystusem drogą, na którą On zaprasza, zwołuje, w której towarzyszy (służy) przez swoją wspólnotę wzrostowi wiary poprzez liczne próby i doświadczenia, jakie składają się na historię konkretnego, jednostkowego życia. Katechumenalna inspiracja katechezy pokazuje, że mamy tu do czynienia z poważną propozycją przemiany wewnętrznej, która domaga się obecności i zaangażowania wspólnoty eklezjalnej (wspólnoty podstawowej, wspólnoty rodzinnej), odwagi w otwarciu na rodzące się nowe życie (nowego człowieka) oraz umiejętności włączenia człowieka w jego misję w jego świecie ${ }^{30}$. Młodzi uczestnicy katechezy potrzebują pewności wiary dorosłych/dojrzałych w wierze, dojrzałej pokory w podejściu do człowieka oraz umiejętności akceptującego towarzyszenia im w trudzie stopniowego rozumienia własnego życia i odkrywania własnej misji we wspólnocie. A zarazem świadomości, że nie muszą być „gigantami wiary”, że inicjacja jest dopiero początkiem drogi, po której z czasem nauczą się iść bardziej samodzielnie. Teologiczny charakter katechumenatu wskazuje na fakt, że inicjacja w dojrzałą wiarę rodzi życie chrześcijańskie (albo - jeśli na przestrzeni całej egzystencji się powtarza - rodzi to życie ponownie); jest decyzją budowania/odbudowania świątyni Ducha Świętego, jaką jest człowiek ${ }^{31}$. Adelajda Sielepin nazywa tę właściwość zasada inkarnacyjna ${ }^{32}$. Bardzo dobrze widać tę nowość w patrzeniu na adresata w zmianie nazewnictwa: nie „katecheza dorosłych”, ale „z dorosłymi” (i podobnie w innych sytuacjach). Jak zauważa Andrzej Kiciński, „nie chodzi tutaj o prostą zmianę stylistyczną, ale zaproponowanie innego modelu katechezy, w której jej uczestnicy z przedmiotu zainteresowania staną się aktywnym podmiotem na każdym etapie życia i rozwoju wiary" ${ }^{33}$. Chodzi właśnie o to dojrzałe podejście do adresata: nie jako do tego, kogo należy pouczyć, zmienić czy nawrócić, ale z którym razem zmieniać się ma cała wspólnota lub ten, kto stał się szczególnym towarzyszem drogi na danym etapie procesu wtajemniczenia czy mistagogii. To oznacza odejście od traktowania ludzi zarówno w sposób anonimowy, jak i infantylny: w dobie Internetu wiedza, jaką zdobędzie uczeń, może okazać się bardziej inspirująca niż ta, którą posiada „nauczyciel religii” czy „duchowy przywódca” (formator nieświadomy własnych

30 Zob. A. Zuberbier, Teologia wtajemniczenia chrześcijańskiego, w: Nowe życie w Chrystusie, S.A. Porębski (red.), Warszawa 1973, s. 57-66.

31 Metanoia to permanentne wezwanie do ciągłego rodzenia się na nowo. Warto zwrócić uwagę na wybitnie personalistyczny charakter metody katechumenalnej. Zob. P.T. Goliszek, Personalistyczny wymiar katechezy, Lublin 2017, s. 383-397.

32 Zob. A. Sielepin, Ku nowemu życiu. Teologia i znaczenie chrześcijańskiej inicjacji dla życia wiara, Kraków 2014, s. 347-357.

${ }^{33}$ A. Kiciński, Rozwój dyrektoriów katechetycznych, s. 24. 
ran duchowych czy emocjonalnych staje się jak „ślepy, który prowadzi ślepego”). Odnowa katechezy oznacza zatem, że stajemy razem jako jeden Kościół zbawionych grzeszników, odkrywający w drodze obecność Mistrza.

\section{Podsumowanie}

Radosław Mazur zauważył, iż „konieczność dostosowania katechezy do sytuacji i kontekstu życia adresatów sprawia, że w każdej epoce historycznej, w każdym miejscu czy w każdym kontekście kulturowym, możemy mówić zarówno o tych samych adresatach katechezy (każdy człowiek), jak i nowych jej odbiorcach (człowiek zawsze konkretny, zawsze nowy)"34. Historia katechezy pokazuje, jak ważna jest świadomość tego, że odbiorca się zmienia. Prawda, którą Kościół ma żyć w świecie, nie da się ująć w żadnym katechizmie; ona rodzi się w codziennym zmaganiu się o kształt naszych ludzkich więzi i jakości życia. Ogromnym wyzwaniem dla współczesnego świata jest „kapitał społeczny”: umiejętność budowania zdrowych, dojrzałych relacji międzyludzkich. Kościół staje dzisiaj wobec adresata, który nie za bardzo potrafi budować takie relacje; mamy bardzo niski wskaźnik zaufania społecznego, wysoki wskaźnik rozwodów, żyjemy w świecie wielu konfliktów i nadmiaru informacji. Znamienne, że na te czasy Duch postawił między nami papieża, którego wizję duszpasterstwa wypełniają takie określenia jak dynamizm, pasja, entuzjazm, spotkanie, przyjaźń, zaangażowanie, towarzyszenie, działanie przemieniające, bliskość, cierpliwość, gościnność, radość, otwarcie na dialog, serdeczne spojrzenie, słuchanie, roztropność, zrozumienie, wzruszenie itp. Jan Szpet pisze: „Sztuka towarzyszenia wymaga zdolności słuchania, szacunku, zrozumienia, współczucia, by wyzwalała do wzrastania, a przekaz dokonywał się nie drogą pouczania i jedynie komunikacji prawdy, ale powodował bliskość serc"35. To pokazuje, z jakim nowym adresatem musimy się dzisiaj zacząć liczyć. Może dlatego nowe Dyrektorium kończy się słowami: „Maryja wychowywała Jezusa [...] w domowej atmosferze skromności, czułości, kontemplacji i troski o innych. Sama też, jako Matka, uczyła się podążania za Synem, stając się pierwszą i najdoskonalszą spośród Jego uczniów" (DK 218).

Słowa kluczowe: Dyrektorium o katechizacji, współczesny człowiek, odbiorcy katechezy.

\footnotetext{
Abstract

The author analyzes the text of the new Directory on catechesis - in its integral reference to the understanding of contemporary man, the recipient of catechesis, but also of

${ }^{34}$ R. Mazur, Nowi adresaci katechezy, s. 195.

35 J. Szpet, Inspiracje katechetyczne Evangelii gaudium. Wybrane aspekty, „Katecheza” 11(2013), s. 59.
} 
evangelization - trying to understand who the new addressee of catechesis is. He adopts a double perspective of thinking about the addressee: first, he refers to quantitative criteria, specifying individual social or ecclesial groups, then he refers to the quality criteria, pointing to the selection of their research level in the development of faith or the initiation point. It seems that the Authors of the document are aware of the complexity of the situations, in which the work of proclaiming the Good News takes place, although - as is usually the case with documents - they do not resolve a number of problems from the point of view of the organization of work. The author refers to the earlier Directory and to other important documents of Church (especially Pope Francis) that may clarify some of the overly general statements in the new Directory. The author puts the question of whether the new document might become a new impulse for understanding the new addressees of catechesis.

Keywords: directory for catechesis, contemporary human, catechesis addressees.

\section{Riassunto}

L'autore analizza il testo del nuovo Direttorio sulla catechesi nel suo integrale riferimento alla comprensione dell'uomo contemporaneo, come destinatario della catechesi, ma anche dell'evangelizzazione, cercando di capire chi sia il nuovo destinatario della catechesi. Si adotta una doppia prospettiva di percezione del destinatario: la prima si riferisce a criteri quantitativi, specificando i singoli gruppi sociali o ecclesiali, l'altra si riferisce ai criteri di qualità, indicando la selezione del loro livello di ricerca nello sviluppo della fede o momento dell'avviamento. Gli Autori del documento sembrano consapevoli della complessità delle situazioni, in cui si opera l'annunzio della Buona Novella, sebbene, come sovente accade con i documenti, non risolvano alcuni problemi dal punto di vista strutturale del lavoro. L'autore si relaziona con il Direttorio precedente e con gli altri importanti documenti della Chiesa (soprattutto quelli di papa Francesco) che possono chiarire alcune delle affermazioni troppo generiche del nuovo Direttorio. L'autore si chiede se il nuovo documento possa diventare un nuovo punto di partenza per la comprensione dei nuovi destinatari della catechesi.

Parole chiavi: direttorio sulla catechesi, uomo contemporaneo, destinatari della catechesi.

\section{Bibliografia}

Benedykt XVI, Katechezy o Ojcach Kościoła, Kraków 2008.

Benedykt XVI, List o przyczynach kryzysu Kościoła, Kraków 2019.

Blachnicki F., Istotne cechy ruchu eklezjalnego, Kraków 2018.

Chyła J., Ewangelizacja cyfrowego kontynentu, „Kultura - Media - Teologia” 22(2015).

Franciszek, Bądźcie uczniami i misjonarzami Chrystusa. Wystąpienie papieża podczas

Liturgii Słowa Święta Powitania 28. Światowych Dni Młodzieży, Rio de Janeiro, 25 lipca 2013, „Wiadomości KAI” 31(2013).

Franciszek, Bez Kościoła nie możemy być zbawieni. Audiencja generalna, 25 czerwca 2014, „Wiadomości KAI” 27-28(2014).

Franciszek, Kościót jest posłany, aby nieść Ewangelię całemu światu. Audiencja generalna, 16 października 2013, „Wiadomości KAI” 43(2013). 
Franciszek, Nawróćmy się na nowość Ewangelii, budujmy sieć solidarności. Homilia Franciszka wygłoszona podczas mszy św. z udziałem filipińskich biskupów, księży i osób konsekrowanych, Manila, 16 stycznia 2015, „Wiadomości KAI” 4(2015).

Gogolik M., Katecheza parafialna dorosłych w kontekście nowej ewangelizacji, „Katecheza” 11(2013).

Goliszek P. T., Personalistyczny wymiar katechezy, Lublin 2017.

Ihnatowicz J., Adresaci katechezy. Omówienie IV części Dyrektorium Ogólnego o Katechizacji, „Katecheta” 6-7(1998).

Jan Paweł II, II Synod Biskupów poświęcony Europie. Rozważanie przed modlitwą Anioł Pański, „L'Osservatore Romano” 9(1996).

Kiciński A., Rozwój dyrektoriów katechetycznych po Soborze Watykańskim II (1971 - 1997 - 2020), „Roczniki Teologiczne” 11(2020).

Kłocińska A., Karnawał wobec sacrum. O ludyczności kultury współczesnej, „Kultura i Wartości” 3(2012).

Kopiczko T., Nowe fora katechezy, „Studia Katechetyczne” 13(2017).

Kurzydło D., Formacja dorosłych $w$ dojrzałej wspólnocie chrześcijańskiej. Współczesna perspektywa, w: Problemy dorosłych ludzi. Formacja chrześcijańska dorosłych a codzienne trudności życia, Kurzydło D. (red.), Warszawa 2014.

Mazur R., Nowi adresaci katechezy?, „Studia Katechetyczne” 10(2014).

Misiewicz J., Adresaci katechezy według Dyrektorium ogólnego o katechizacji, w: Kościót katechizujacy i katechizowany, red. I. Dec, Wrocław 2003.

Nawrócenie duszpasterskie wspólnoty parafialnej w służbie misji ewangelizacyjnej Kościoła, Wrocław 2020.

Ratzinger J., Co jest konstytutywne dla wiary chrześcijańskiej dzisiaj, w: „Opera Omnia” 9(2018)1, Lublin 2018.

Sielepin A., Ku nowemu życiu. Teologia i znaczenie chrześcijańskiej inicjacji dla życia wiara, Kraków 2014.

Szpet J., Inspiracje katechetyczne Evangelii gaudium. Wybrane aspekty, „Katecheza” 11(2013). Wita G., Areopagi nowej ewangelizacji, „Studia Salvatoriana Polonica” 6(2012).

Zuberbier A., Teologia wtajemniczenia chrześcijańskiego, w: Nowe życie w Chrystusie, Porębski S.A. (red.), Warszawa 1973.

\section{O autorze}

ks. Dariusz KURZYDŁO - prof. UKSW, dr hab. Od 1995 r. prezbiter diecezji koszalińsko-kołobrzeskiej. Teolog i psycholog. Autor książek „Koncepcja katechezy dorosłych we współczesnych dokumentach Kościoła” (2013) i „Rytuały przejścia a bierzmowanie. Próba zastosowania psychologii antropologicznej do katechezy młodzieży” (2015). Pracuje na Wydziale Teologicznym UKSW w Warszawie. 